AD-A094 017 HARCO CORP MEDINA OH

PIPE-TO-SOIL POTENTIAL LIMITS FOR PROTECTIVE COATINGS, (U)

F/G $11 / 3$

NOV 80 B HUSOCK

$F 08635-77-C-0248$

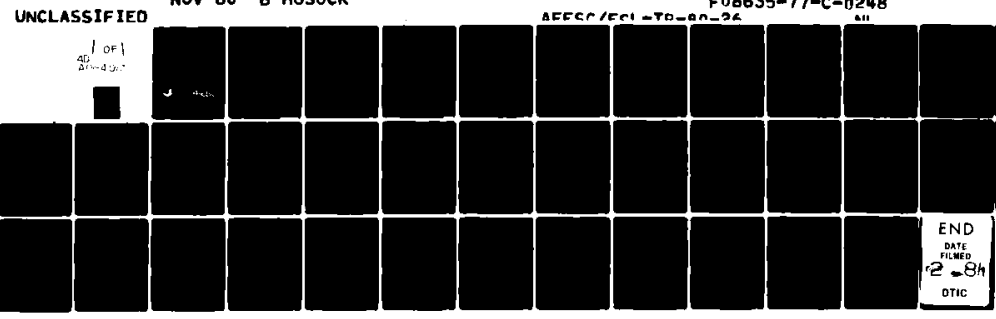




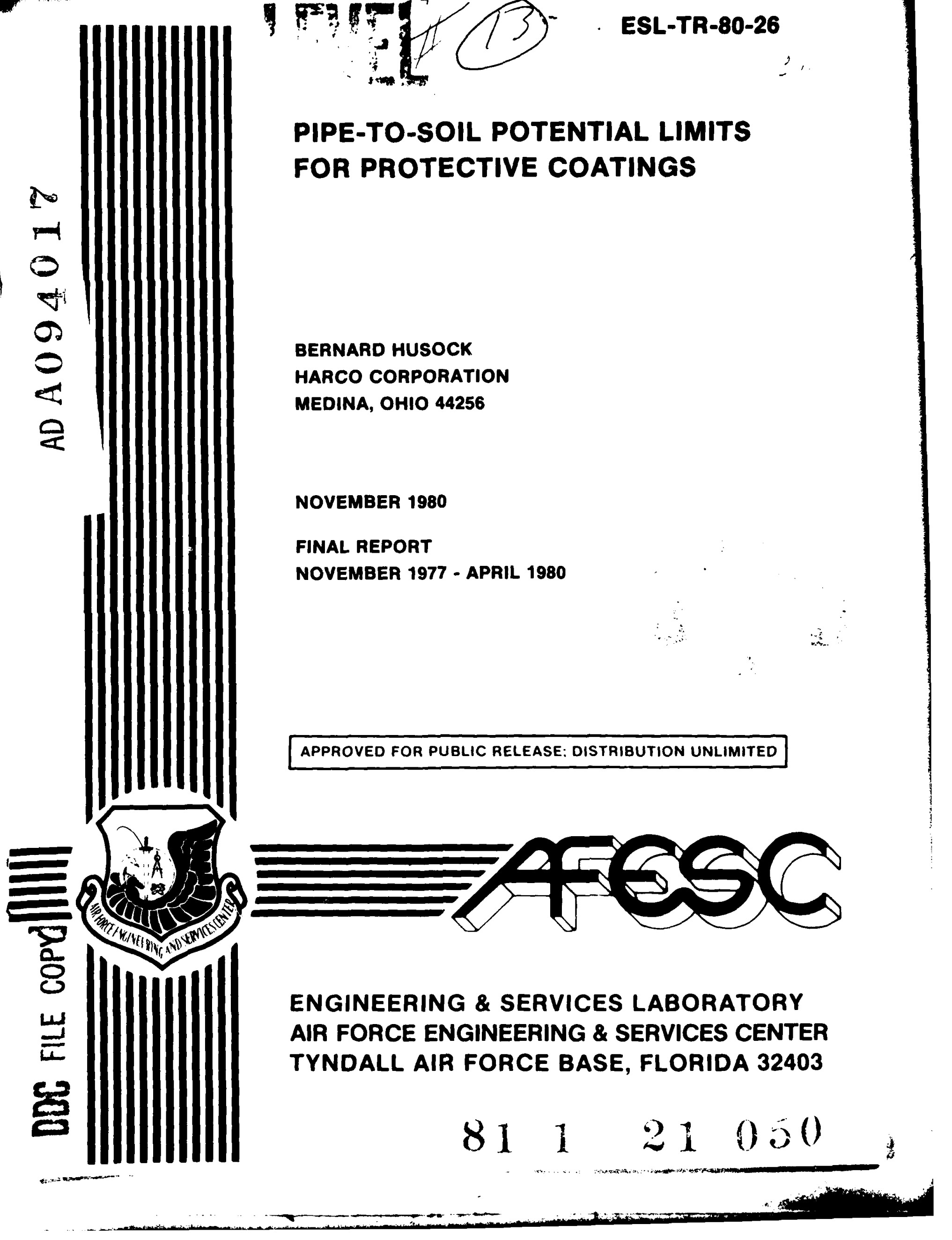




\title{
NOTICE
}

Please do not request coples of this report from HQ AFESC/RD (Engineering and Services Laboratory). Additional copies may be purchased from:

\author{
National Technical Information Service \\ 5285 Port Royal Road \\ Springfield, Virginia 22161
}

Federal Government agencies and their contractors registered with Defense Technical Information Center should direct requests for copies of this report to:

Defense Technical Information Center

Camieron Station

Alexandria, Virginia 22314 
UNCLASSLELEV

SECUMITY CLASSIFICATION OF THIS PAGE (Whon Date Entered)

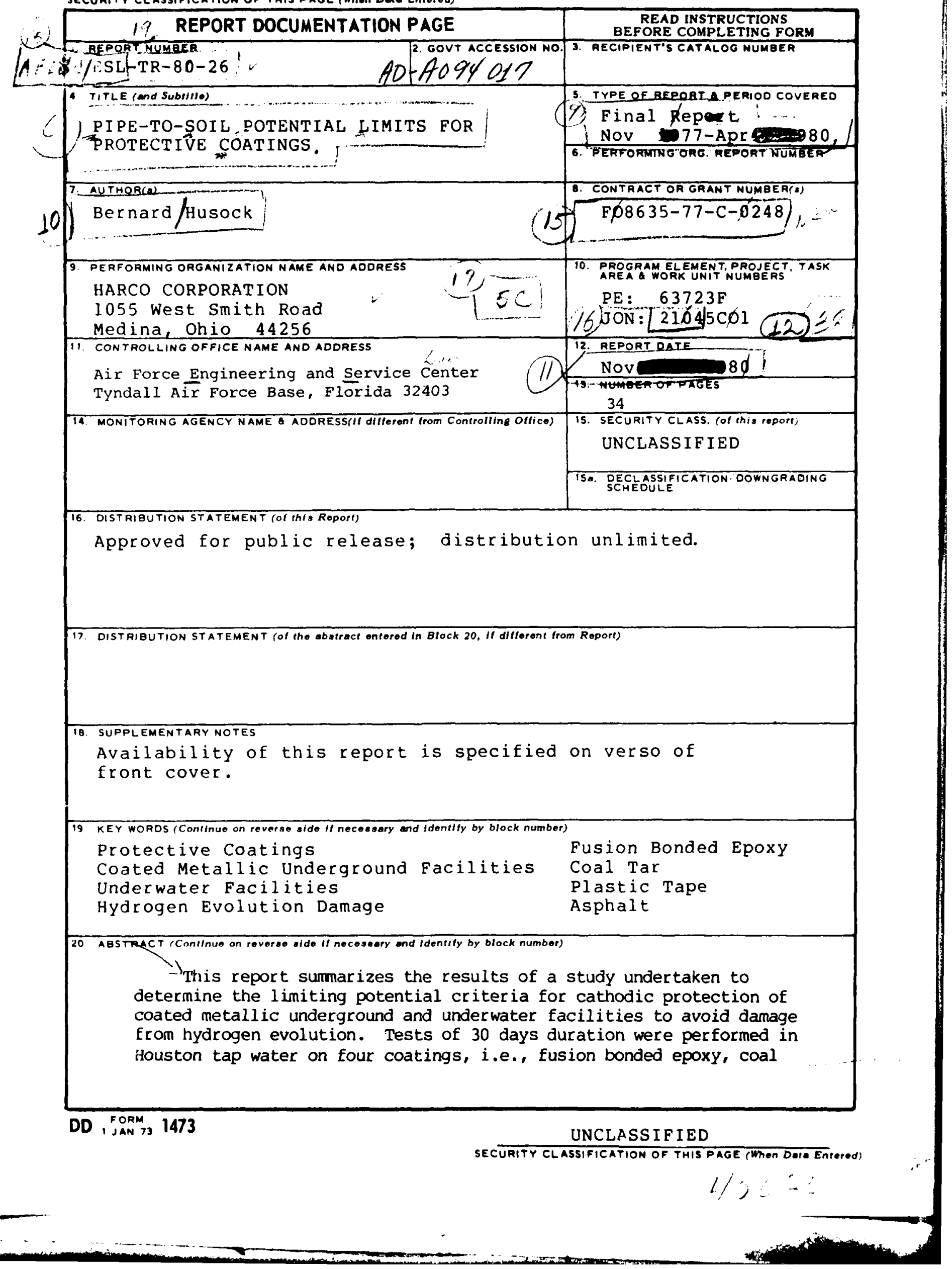


INACRASSTEIFD

SECUAITY CLASSIFICATION OF THIS PAGE(mmen Dete Entored)

\section{ABSTRACT (CONCLUDED)}

; tar, plastic tape and asphalt. Each coating was cathodically protected at polarized instant off potential levels of $-1.02,-1.07$, -1.12 , -1.17 , and -1.22 volts to copper-copper sulfate. It was found that hydragen evolution is initiated at a polarized potential of -1.12 volts and becomes more vigorous as the applied current is increased. The polarized potential value increases as the current increases only up to a value of -1.22 volts. An increase in applied current beyond that value increases the hydrogen evolution and increases the an potential, but there is no measurable increase in the OFF potential...

-The different coatings tested reacted differently in these tests. These short terin tests should not be used for comparison of disbondment resistance. One coating experienced disbondment at an OFF potential where no gas was evident, and another coating experienced no disbondment even at -1.22 volts under vigorous hydrogen evolution. 


\section{PREFACE}

This report was prepared by Harco Corporation, 1055 West Smith Road, Medina, Ohio 44256 under Contract No. F08635-77-C-0248 with the Air Force Engineering and Services Center, Tyndall Air Force Base, Florida 32403. The work was begun in November 1977 and was completed in April 1980.

This report has been reviewed by the Public Affairs office (PA) and is releasable to the National Technical Information Service (NTIS). At NTIS, it will be available to the general public, including foreign nations.

This technical report has been reviewed and is approved for publication.
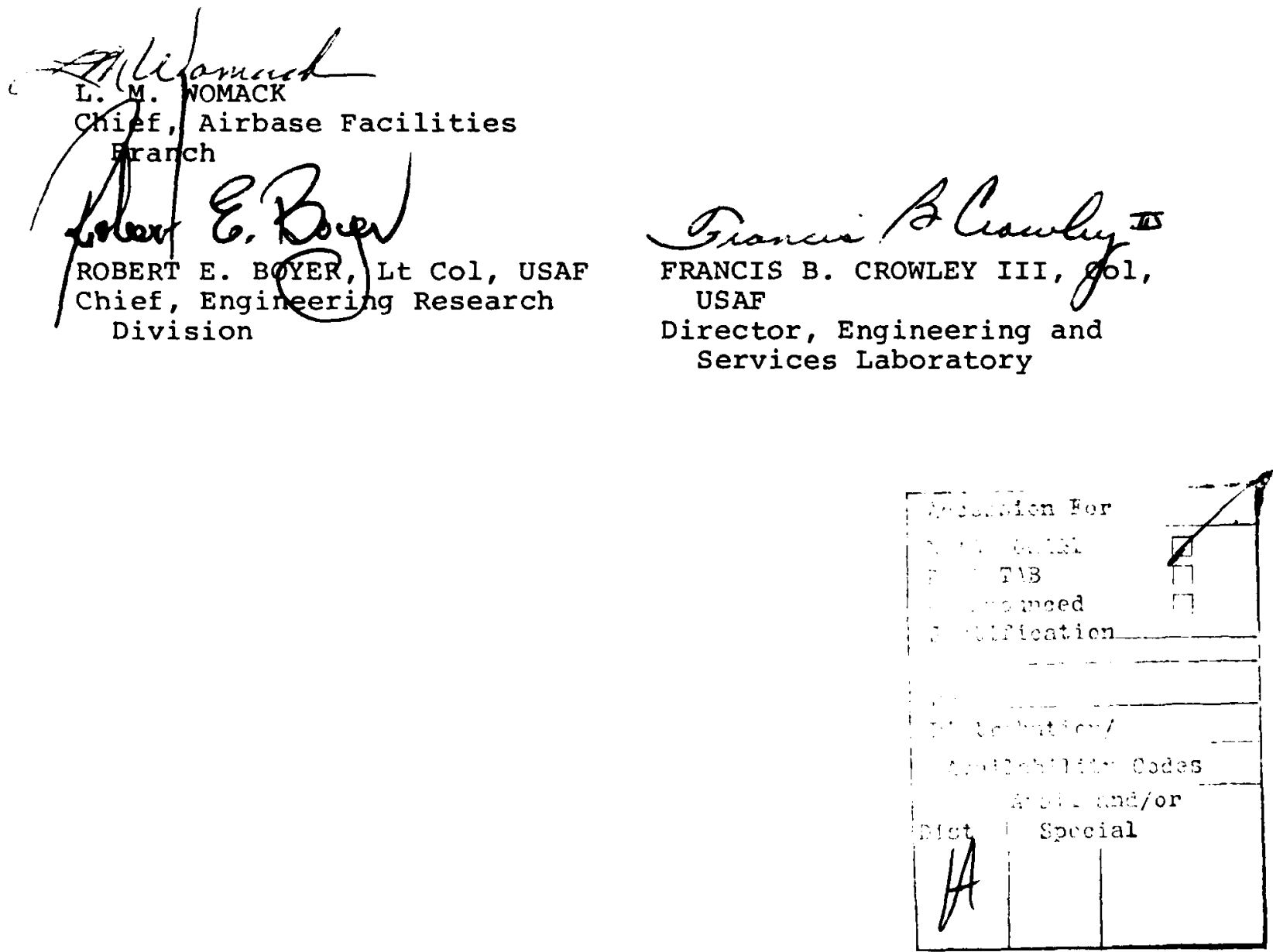

(The reverse of this page is blank) 
TABLE OF CONTENTS

Section

I

II

II I

IV

V

Appendix

A

B
Title

Page

INTRODUCTION.$\ldots \ldots \ldots \ldots \ldots \ldots \ldots \ldots \ldots \ldots \ldots \ldots \ldots$

HISTORY AND BACKGROUND. ....................

TESTING PROCEDURES.........................4

RESULTS AND DISCUSSION....................

A. General $. . . \ldots \ldots \ldots \ldots \ldots \ldots . . \ldots . . . \ldots 9$

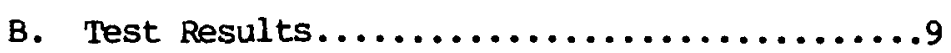

c. Physical Examination...................19

CONCLUSIONS............................20

REFERENCES............................21

Coating Specifications...................... 23

Houston Tap Water Analysis Results............. 31 


\section{LIST OF FIGURES}

Figure

Title

Page

1 Physical Arrangement of Components......................... Coating Disbondment Tests

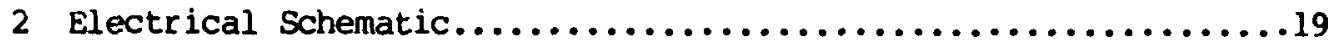
Coating Disbondment Tests

\section{LIST OF TABLES}

Table

Title

Page

1. Cathodic Protection Disbondment Test....................10

Fusion Bond Epoxy

2. Coal Tar Enamel..................................11

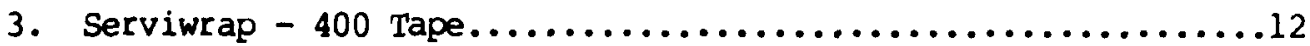

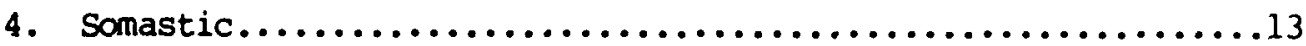

5. Fusion Bonded Epoxy - Apparent Resistance in Ohms...........15

6. Coal Tar Enamel - Apparent Resistance in Ohms.............16

7. Tape - Apparent Resistance in Ohms......................

8. Asphalt - Apparent Resistance in Ohns.....................

9. Disbondment Results............................... 18 


\section{INTRODUCTION}

The recommended practice for control of corrosion on underground pipelines requires "coating supplemented with cathodic protection" (Reference 1). This practice recognizes that cathodic protection is necessary to achieve complete corrosion control on coated pipe. Experience with coated pipe that is not cathodically protected has shown that corrosion is of ten accelerated at discontinuities (or holidays) in the coating. Because practical pipe coatings cannot be expected to be absolutely flawless, coating together with cathodic protection has been found to be "the best combination of the two means of corrosion prevention" (Reference 2).

Despite the fact that coating together with cathodic protection is acknowledged to be an ideal combination, it is also acknowledged that cathodic protection can have deleterious effects on pipe coatings. These effects result from two basic mechanisms: (1) alkalinity sufficient to "cause the deterioration" and (2) "hydrogen produced at flaws in a coating may progressively detach the coating from the surface of the metal" (Reference 3 ). These adverse effects do not usually create problens at the normal levels of cathodic protection, but "excessive cathodic protection can cause or accelerate deterioration of coatings" (Reference 4). Because the level of cathodic protection applied to a pipeline is determined by the value of pipe-to-soil potential, an increase in the level of cathodic protection results in more negative values of pipe-to-soil potential. Backstom and Causey (Reference 4 ) indicate that the adverse effects "occur primarily at cathodic protection levels which are substantially nigher than normally used to protect metal structures," and the British Code of Practice states that "the effect can be minimized by avoiding the use of very negative potentials" (Reference 3 ).

Despite statements such as the above, there is little substantive information in the literature to indicate what is actually meant by "substantially higher than normally used."

Therefore, it can be seen that there is a basic question concerned with determining specific potential levels beyond which coatings become susceptible to damage. Thus, the objective of this study is to determine and demonstrate the limiting surface potential criteria to be measured over underground and under water facilities to avoid damage to protective coatings from hydrogen evolution.

This study is concerned only with the determination of the damage which can result from hydrogen evolution. Damage which can result from the increased alkalinity was not considered in this study. 


\section{HISTORY AND BACKGROUND}

It is generally agreed that free hydrogen gas, generated when the cathodic protection potential exceeds the nydrogen overvoltage, exerts pressure at flaws in a coating thereby causing damage to that coating. Although the exact value of the hydrogen overvoltage potential can vary in different electrolytes, the value for iron and steel in naturally occurring electrolytes is approximately -1.20 volts to a copper-copper sulfate reference electrode (Reference 5 ). This potential is a polarized potential or the potential measured at the instant when the cathodic protection current is turned off; it is of ten referred to as the "instant off" potential.

Despite the fact that the value of hydrogen overvoltage is a polarized potential, the literature on the subject of cathodic protection disbondment almost always refers to potential measurements taken with the cathodic protection current applied with little or no attention given to consideration of IR drop. Thus, the British code states that "structure/electrolyte potentials more negative than $-2.5 \mathrm{~V}$ should be avoided on buried structures" (Reference 6). Salt crock tests described by Hunter (Reference 7) and others (Reference 8), were conducted at pipe-to-electrolyte potentials of -3.0 volts to a calomel electrode with the current applied. Salt crock testing by the Columbia Gas System Service Company (Reference 9) used 6 volts across the test cell and protective potentials of -1.0 and -1.5 volts to a copper-copper sulfate electrode. In coating tests on buried pipes, Goose (Reference 10) describes work in which samples were maintained at pipe-to-soil potentials of -3.0 volts and -1.5 volts to copper-copper sulfate with the cathodic protection current applied. Backstrom and Causey (Reference 11) desc:ibe work on a variety of coatings conducted presumably in fresh water (no information about the water is given) in which the copper-copper sulfate reference electrode was positioned remote from both the anode and the test specimen, and cathodic protection levels were maintained at values of $-1.10,-1.25$, -1.35 , and -1.50 volts with the current applied. The standard methods for testing for cathodic coating disbondment issued by ASTM (References 12 and 13) describe tests performed with the cathodic protection current applied.

All potential measurements taken with cathodic protection applied include a voltage (IR drop) component which is added numerically to the absolute value of the polarized instant off potential (the reading is more negative tnan the polarized potential). The value of the voltage (IR drop) or the difference between the on potential and the "instant off" potential is a function of the coating conductance, the electrolyte resistivity, the position of the reference electrode with respect to the pipe, and the magnitude of the applied current. In testing work such as that described in the above references, in which only the ON potentials are of concern, identical ON potentials in Jifferent tests would not necessarily be indicative of identical plarized potentials. Because hydrogen evolution is a function of the 
"instant of $f$ " potential, testing work to determine the limiting potential to avoid coating damage from hydrogen evolution would be of little value unless the potentials measured were the actual polarized potential of the structure.

Therefore, tests using various values of on potentials, as in the referenced work, were not considered to be appropriate for this study. This study tested the coatings using rectifier units which are automatically controlled to deliver the current necessary to maintain given, pre-set polarized or OFF potentials. This was accomplished using TASC (Total Autonatic Sampling Controller), as described in Section III, Testing Procedures.

1 


\section{SECTION III}

\section{TESTING PROCEDURES}

It was decided to test four types of coatings as follows:

1. Fusion bonded epoxy (thin film)

2. Coal-tar

3. Plastic

4. Asphalt

These types were selected because most of the underground coated pipe is coated with one of these types. The particular commercial coatings used in this work to represent each of these types are as follows:

1. Scotchkote 212 (fusion bonded epoxy).

2. Koppers Bitumastic 70-B Standard Enamel (coal-tar).

3. Servi-Wrap P-400 (plastic).

4. Somastic (asphalt).

These coatings are described in Appendix A. The Scotchkote 212, Bitumastic 70-B, and Servi-Wrap P-400 were applied on pipe specimens each of which was 2 inches in diameter by 12 inches long, schedule 40 , standard steel pipe. The Somastic was applied to specimens 4 inches in diameter by 12 inches long, schedule 40, standard steel pipe. All coatings were applied in accordance with the manufacturer's recommendations by conmercial coating applicators who are experienced in the application of the particular coating.

on each specimen, an intentional holiday was cut through the coating to expose bare steel. The size of this holiday was $3 / 4$ inches in diameter. This is considerably larger than the $1 / 4$ inches in dianeter minimum holiday called for in ASTM G8-72 (Reference 12). The reason for using the larger exposed area is to increase the current needed to maintain a given level of potential. The use of larger values of current than ordinarily used in tests such as these, make it easier to monitor the current changes required to maintain the potential level of interest.

The specimens were tested in Houston tap water, an analysis of which is given in Appendix B. The physical arrangement of the components is shown schematically in Figure 1 . The cathodic protection was applied using a TASC IV controlled rectifier as shown in Figure 2. 


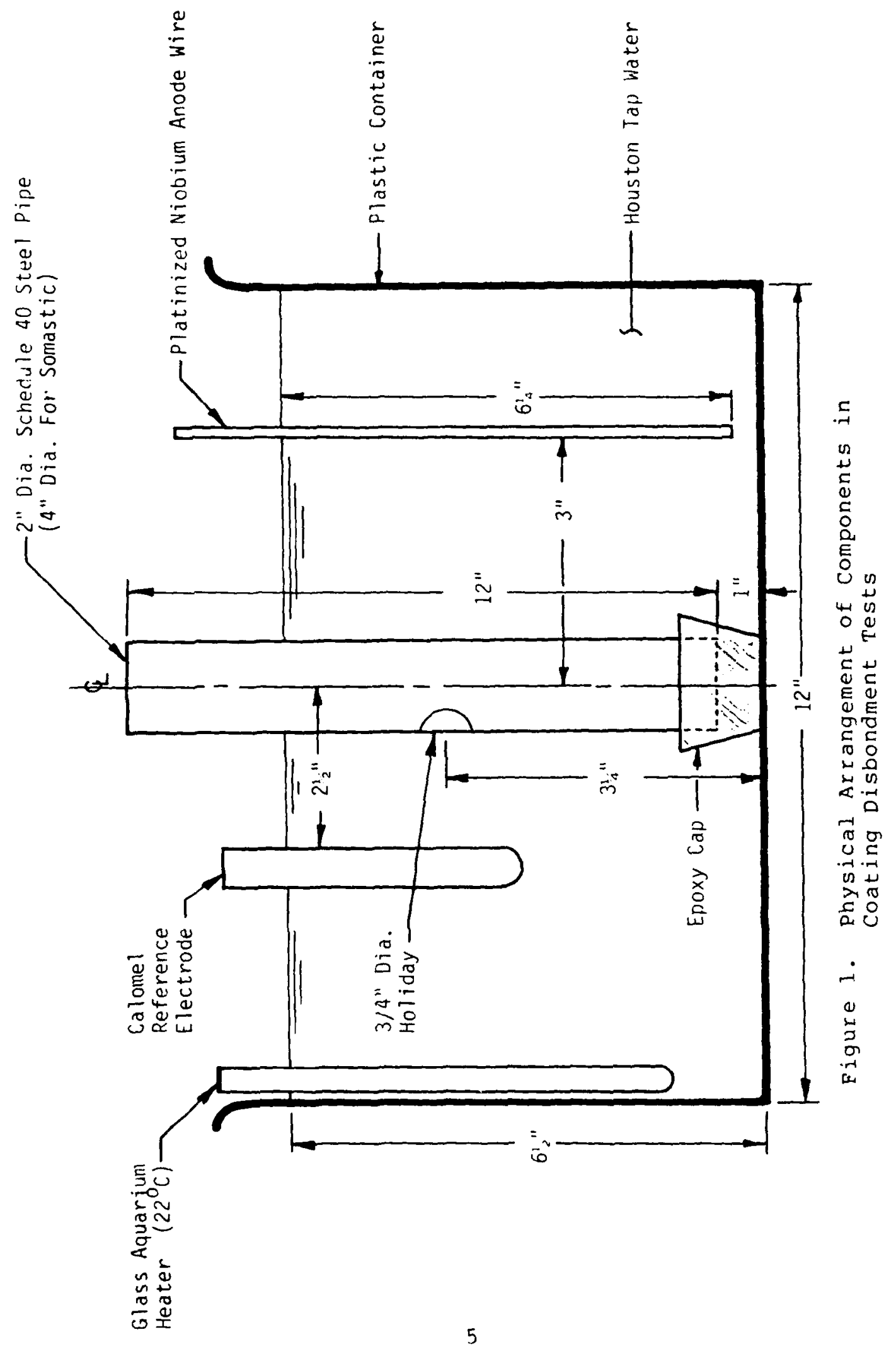




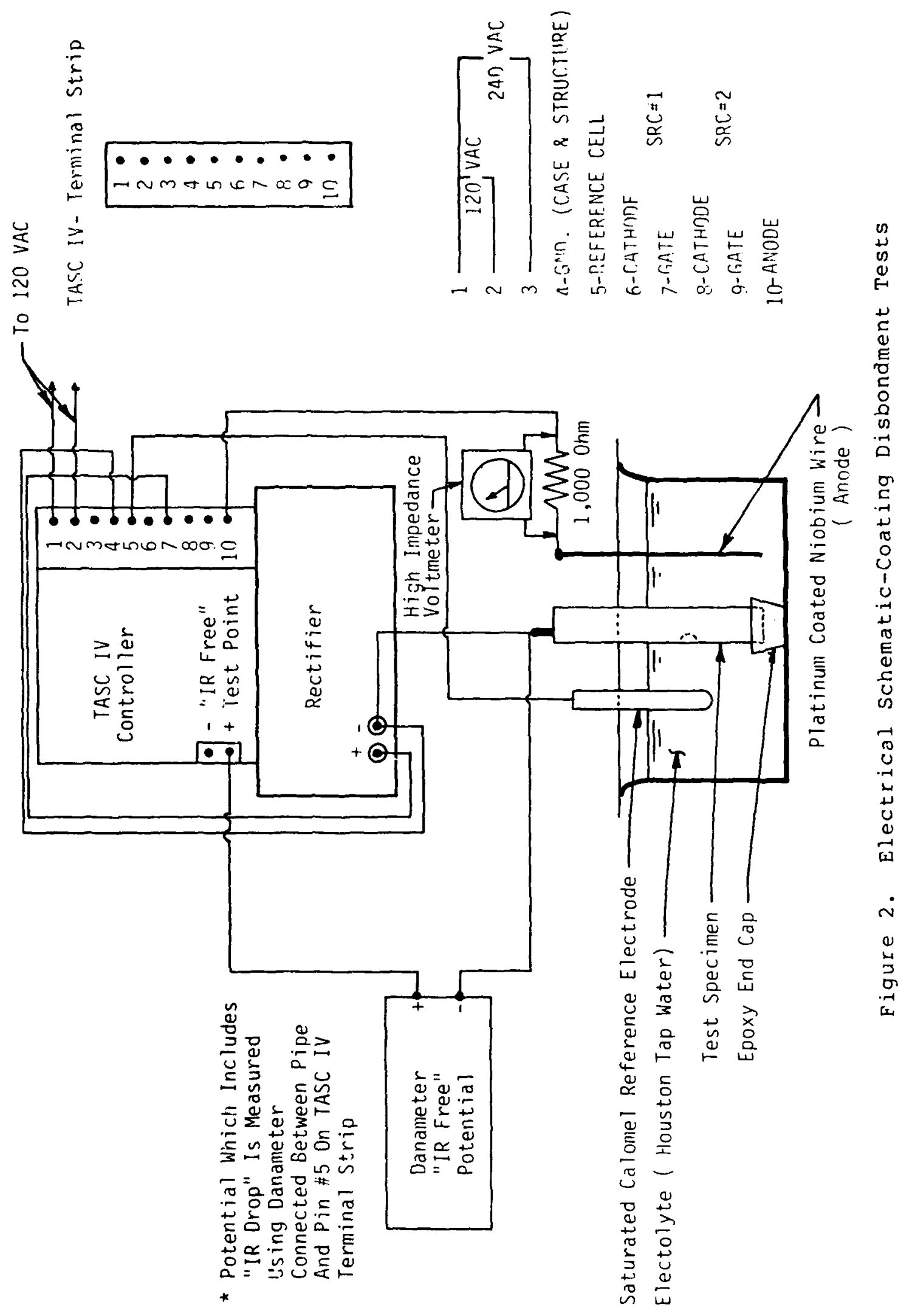


The TASC IV unit used in this study is able to control automatically the applied cathodic protection current necessary to maintain a given level of pipe-to-water potential. The pipe-to-water potentials maintained by this unit are polarized potentials or "instant off" potentials free of IR drop. The TASC IV unit is able to read the polarized potential because the potentials are measured while the current is interrupted for a period of less than 10 milliseconds and the potential is measured at the instant of interruption. If the pipe-to-water potential thus measured is less negative than the potential desired, the rectifier current is automatically increased so that the potential becomes more negative. If the pipe-to-water potential is more negative than desired, the rectifier output current is automatically decreased or turned off entirely, so that the potential becomes less negative. The controller is sufficiently sensitive to maintain a polarized pipe-to-water potential within a ranye of $t 5$ millivolts from a given set value. Because the polarized potentials are measured with the current off, the exact position of the reference electrode with respect to the specimen is not critical.

It was originally intended to run six specimens of each coating for a period of 30 days; one specimen would be unprotected (freely corroding) and the others would be run at the following levels of polarized pipe-to-water potential ( $\mathrm{Cu}-\mathrm{CuSO}_{4}$ reference):

$$
\begin{aligned}
& -1.00 \text { volts } \\
& -1.10 \text { volts } \\
& -1.20 \text { volts } \\
& -1.30 \text { volts } \\
& -1.40 \text { volts }
\end{aligned}
$$

It was found that the value of polarized potential "leveled off" at a value of -1.22 volts and that polarization to potentials more neyative than that value were not possible. Therefore, the testing procedure was modified so that specimens were run at the following values of polarized pipe-to-water potential ( $\mathrm{Cu}-\mathrm{CuSO}_{4}$ reference):

$$
\begin{aligned}
& -1.02 \text { volts } \\
& -1.07 \text { volts } \\
& -1.12 \text { volts } \\
& -1.17 \text { volts } \\
& -1.22 \text { volts }
\end{aligned}
$$

One specimen of each coating was immersed without cathodic protection. 
Potentials were actually measured using a calomel reference electrode, but the equivalent copper-copper sulfate will be given throughout this report. The copper-copper sulfate reading equivalent to calomel is 70 millivolt more negative than the calomel reading. Thus, -1.02 volts to copper-copper sulfate corresponds to -0.95 volts to calomel.

All specimens were run for 30 days and readings were taken each day (except Saturdays and Sundays) of: (1) the polarized pipe-to-water potential (IR drop free) referred to in ihis report as OFF potential, (2) pipe-to-water potential with the current on (includes IR drop) referred to in this report as ON potential, and (3) the protective current. It was expected that the changes in current required to maintain a given polarized potential would be the indicator of coating deterioration. The original thinking was that if the coating remained undamaged, the current required to maintain a given level of protection would remain constant, but if the coating disbonded the current would increase.

After each run was compieted, the specimens were removed, rinsed with distilled water, and examined for coating damage. After the specimens were cleaned, the percent disbondment was estimated by visually comparing the distonded area with the area of the intentional noliday. 


\section{A. GENERAL}

As indicated in Testing Procedures, it was not possible to achieve a pipe-to-water OFF potential of -1.30 volts and -1.40 volts as was originally intended. The maximum OFF potential obtainable was -1.22 volts. Although evolution of hydrogen was observed at lower negative values, the evolution at -1.22 volts become noticably more vigorous. When that potential was reached, an increase in the applied cathodic protection current produced an increased quantity of hydrojen, but there was no significant increase in potential. The potential can be said to level off at that value and more negative OFF potentials could not be obtained even at substantially higher values of current.

This phenomenon was totally unanticipated. Although the cathodic protection literature refers to a polarized potential of approximately -1.20 volts as the value of the hydrogen overvoltage, there was no reference found in the literature search which indicated that there is leveling off at that value.

Because of the unanticipated leveling off of OFF potentials at -1.22 volts, each of the coatings were tested at revised OFF potential levels of $-1.02,-1.07,-1.12,-1.17$, and -1.22 volts, yielding the results described below.

\section{B. TEST RESULTS}

The potential and current values measured during the testing of these coatings are listed in Tables $1,2,3$, and 4.

Review of the data in these tables shows that all four of the coating followed similar patterns of behavior. In the first three specimens of each coating, (those at OFF potentials of $-1.02,-1.07$, and -1.12 volts), the ON potentials remained reasonably constant throughout the test. The corresponding current values on those same specimens decreased as the test progressed. These are the results that would be expected on specimens where the coating remains intact. Film formation at the holiday in the coating is considered responsible for the reduction in the current required to maintain a given level of OFF potential.

Specimens 4 and 5 for all the coatings (those at instant OFF potentials of -1.17 and -1.22 volts) showed more erratic behavior in that the on potentials and the currents varied to a greater degree as the testing proyressed than was the case with the first three specimens. These results are attributed to either the effects of hydrogen gas evolution or coating damage or a combination of both. The instability encountered on specimen 5 is understandable in view of the fact that the OFF potential remained at -1.22 volts, even when the 


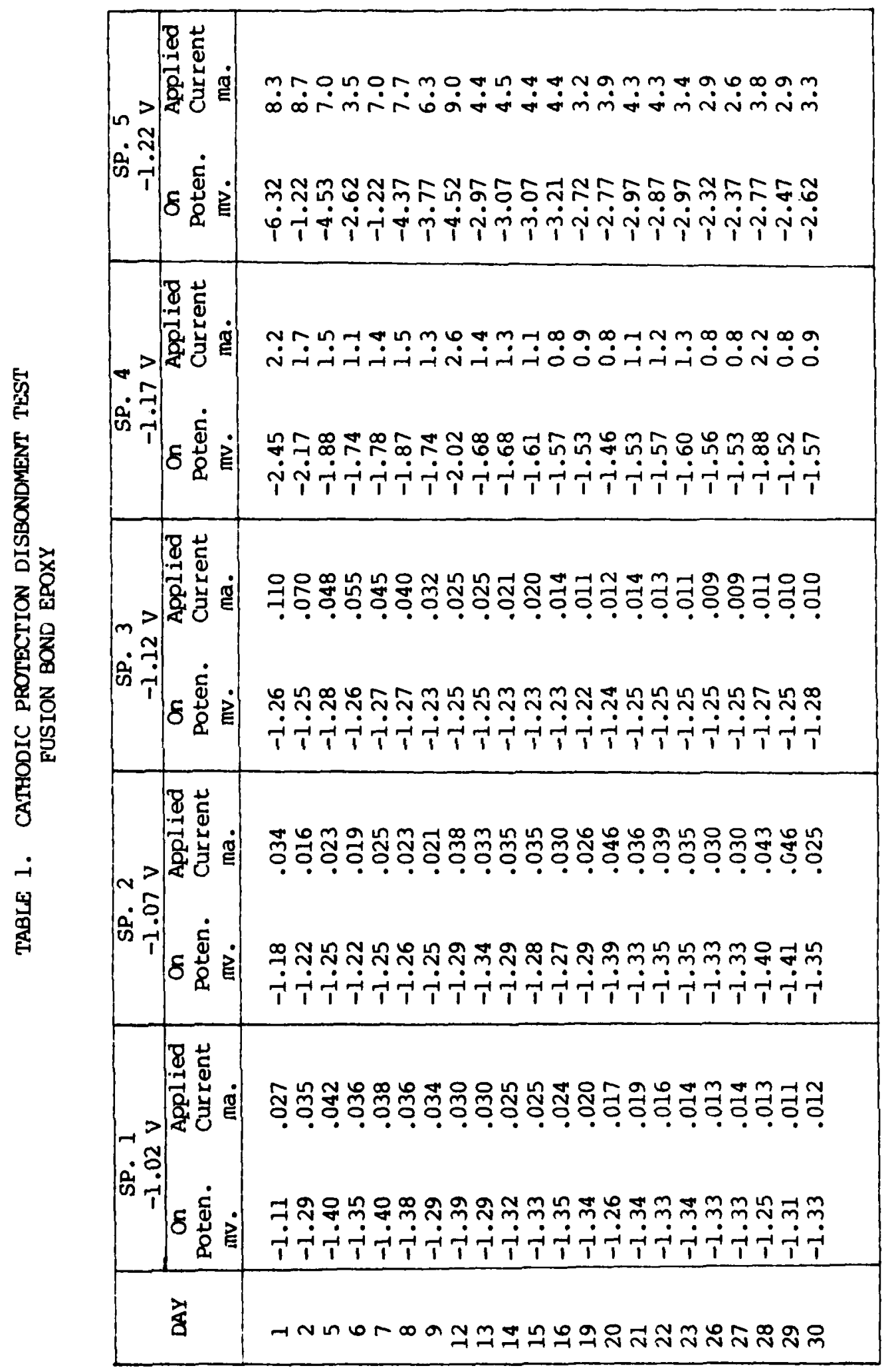




\begin{tabular}{|c|c|c|}
\hline $\ln$ & 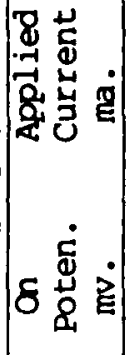 & 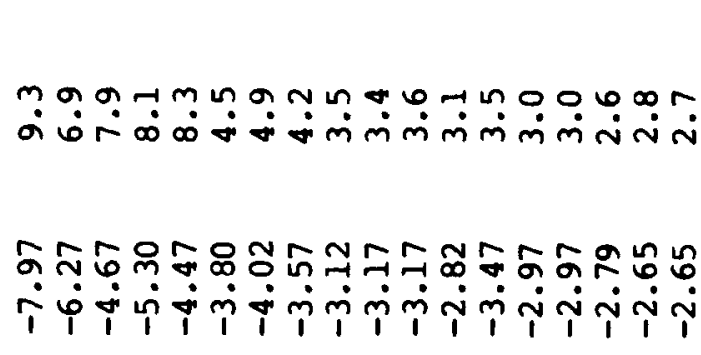 \\
\hline 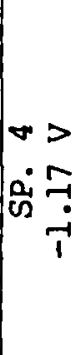 & 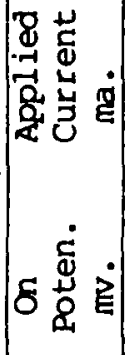 & 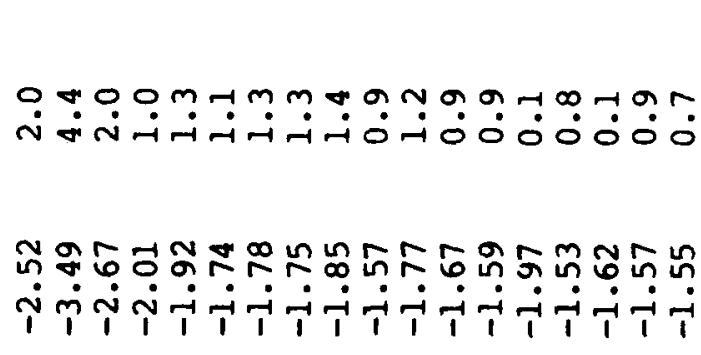 \\
\hline 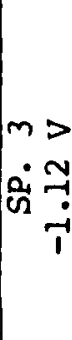 & 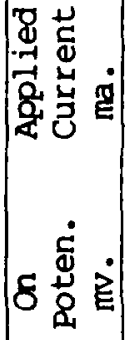 & 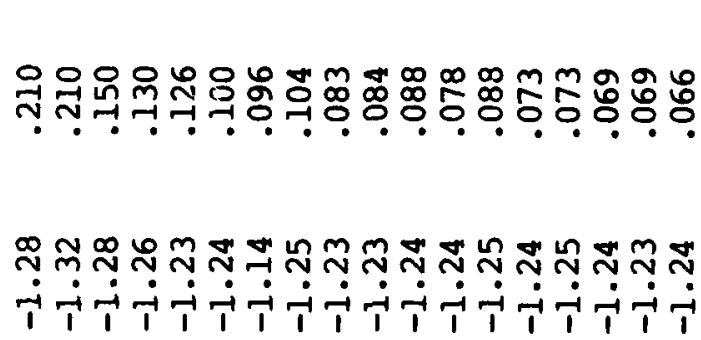 \\
\hline $\begin{array}{l}\sim> \\
\text { में } \\
\text { ñ }\end{array}$ & 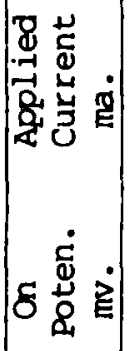 & 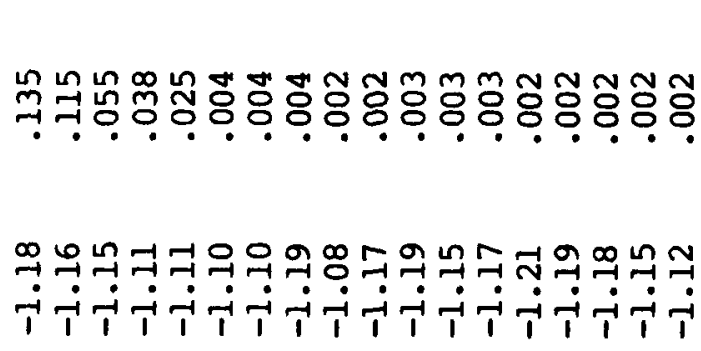 \\
\hline 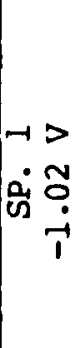 & 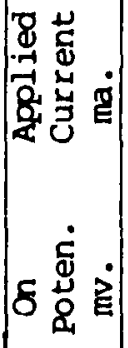 & 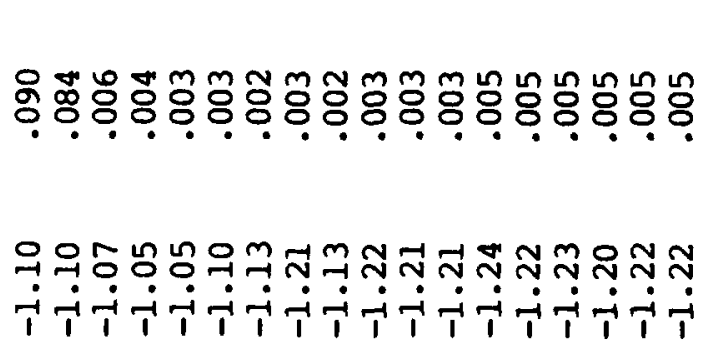 \\
\hline & $\vec{y}$ & ナN ル \\
\hline
\end{tabular}




\begin{tabular}{|c|c|c|}
\hline 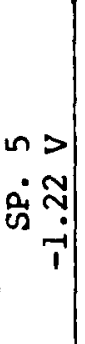 & 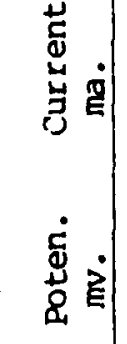 & 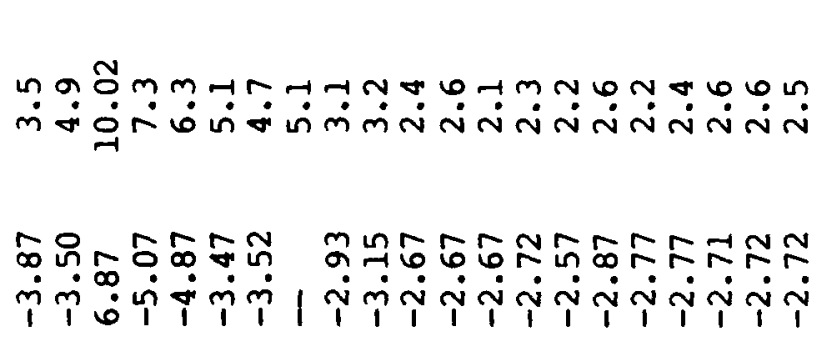 \\
\hline 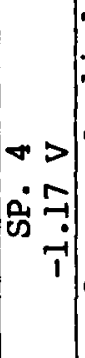 & 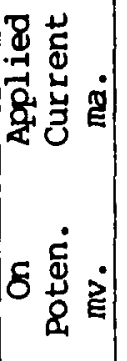 & 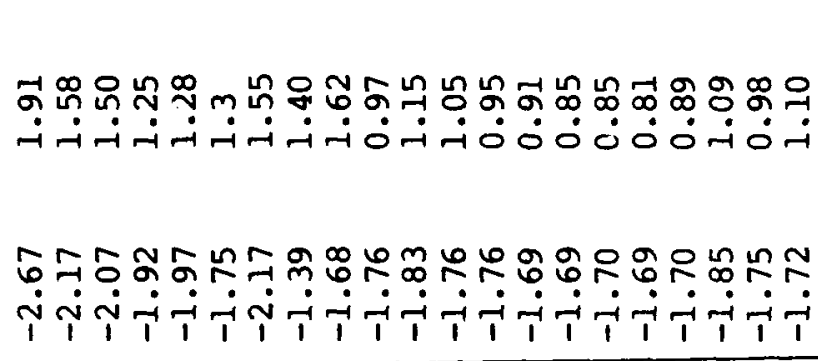 \\
\hline 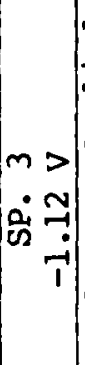 & 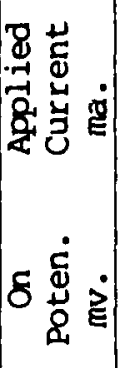 & 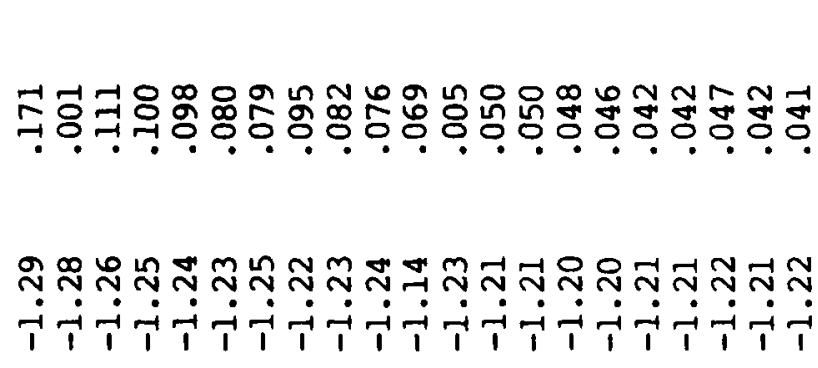 \\
\hline 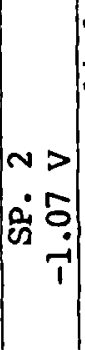 & 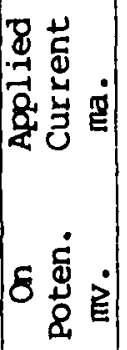 & 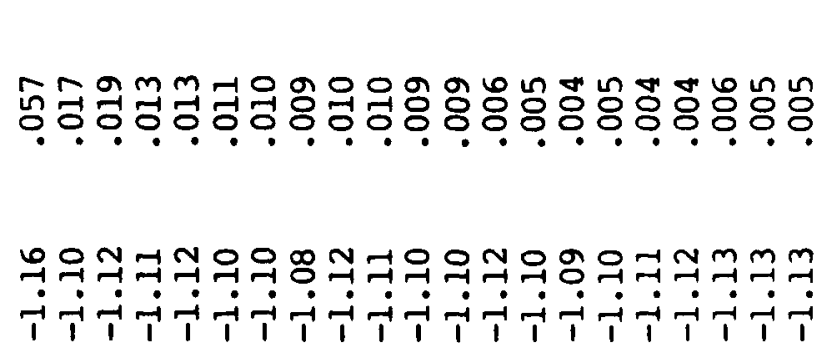 \\
\hline 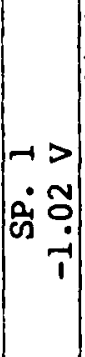 & 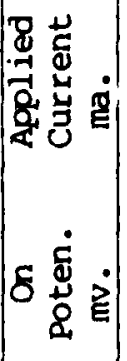 & 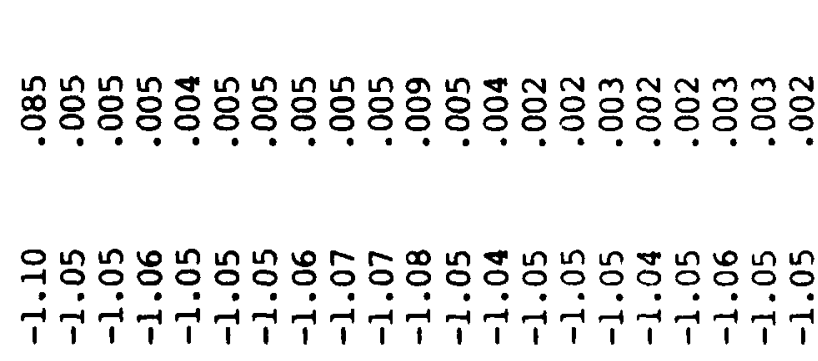 \\
\hline & ไે & 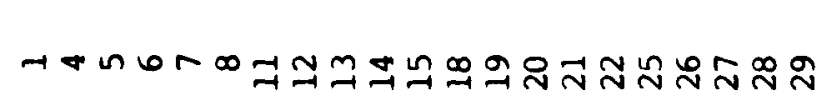 \\
\hline
\end{tabular}




\begin{tabular}{|c|c|c|}
\hline 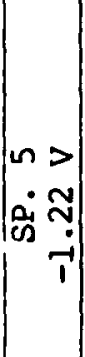 & 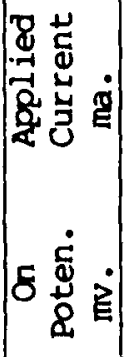 & 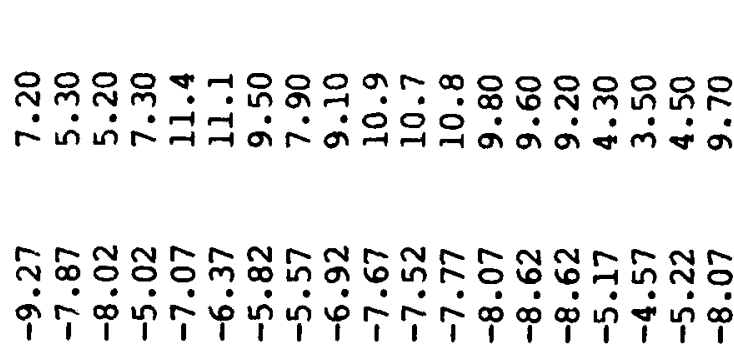 \\
\hline 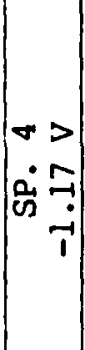 & 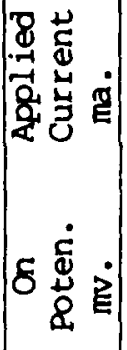 & 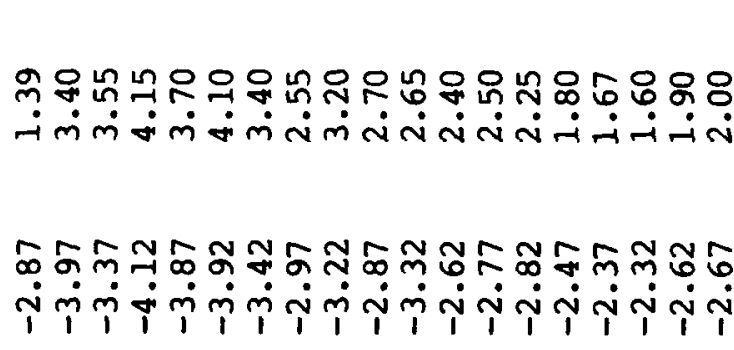 \\
\hline 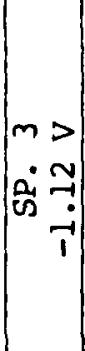 & 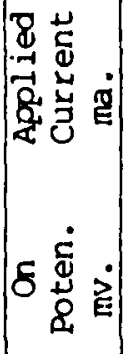 & 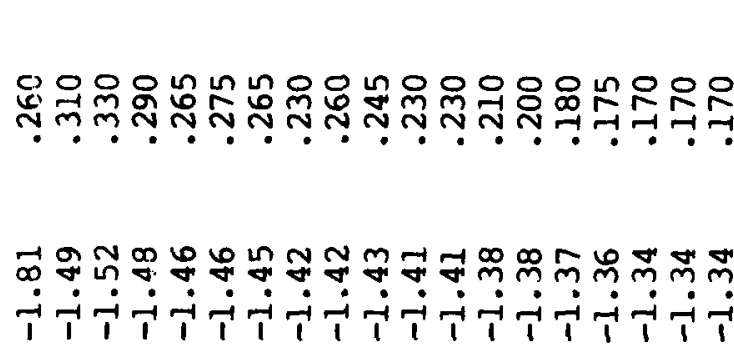 \\
\hline $\operatorname{lin}$ & 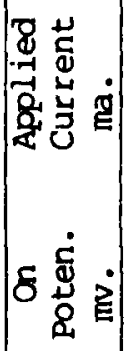 & 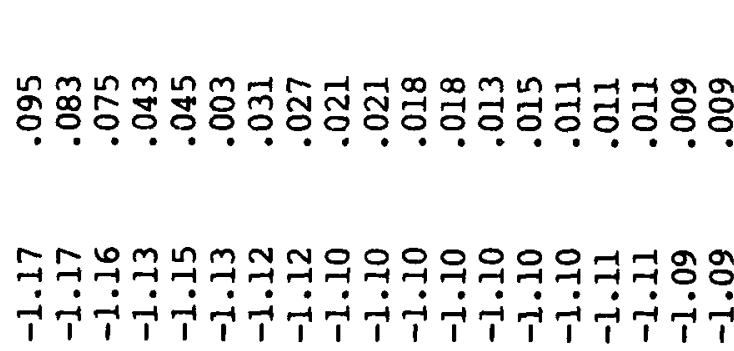 \\
\hline$\rightarrow$ & 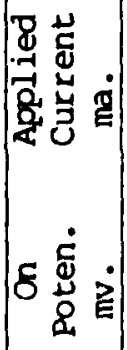 & 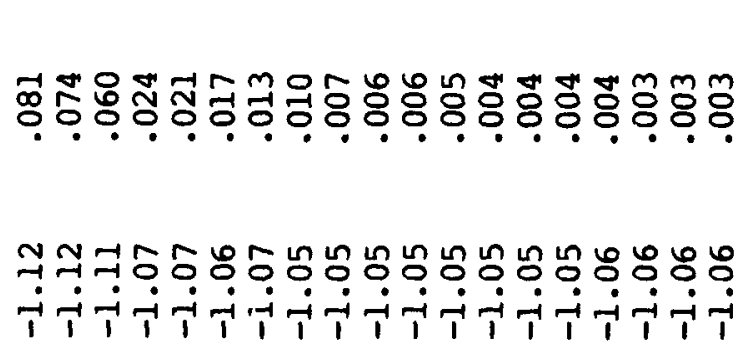 \\
\hline & 䆑 & 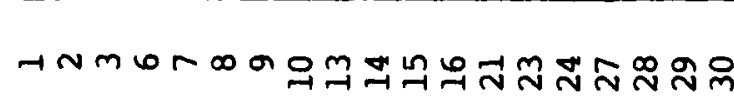 \\
\hline
\end{tabular}


current was increased beyond that which is shown in the tables. An increase in current at -1.22 volts increased the yas generated as well as the on potential, but did not increase the OFF potential. Thus, it can be seen that the ON potentials had no direct relationship to the OFF potential particularly on Specimens 5 . This condition was also the case for Specimens 4. It can be seen that the values of ON potential vary even though the OFF potentials are maintained at a constant value. Thus, it can be stated that the value of on potential is not a valid indicator for use in ascertaining coating disbondment under conditions where hydrogen is being evolved.

In an attempt to find correlations among the results for each of the types of coatings, the values of current and potential measured on each coating were used to calculate values of apparent resistance as follows:

$$
\begin{aligned}
& R=\frac{E \text { on }-E \text { off }}{I} \\
& \text { where } \\
& R=\text { Apparent resistance of the specimen, ohins } \\
& E_{\text {on }}=\text { Pipe-to-water potential with cathodic protection } \\
& \text { current on, millivolts. } \\
& E_{\text {off }}=\text { Pipe-to-water potential, instant of } f_{\text {, }} \\
& I=\quad \text { Applied current, milliamperes. }
\end{aligned}
$$

The values thus calculated for the various coatings are listed in Tables 5, 6, 7 and 8. The pattern which emerges from comparing the values calculated shows that there are similarities in the results at same levels of cathodic protection for the various coatings.

For example, specimens of all coatings which were maintained at -1.02 volts showed considerable increases in resistance as the test progressed. Similarly, specimens of all of the coatings maintained at -1.07 volts, except for asphalt, also showed large increases in resistance although not in the amount seen at -1.02 volts. The resistance of the asphalt specimen also increased at that potential level, but by a lesser factor than the others. All of specimens 3 $(-1.12$ volts) showed resistance values which remained relatively unchanged as the tests progressed except the fusion bonded specimen. On that coating, the resistance of specimen 3 increased in a manner similar to that seen on Specimens 1 and 2 . The resistance of Specimens $4(-1.17$ volts) and Specimens 5 ( -1.22 volts) of all coating started at relatively low values and remained low or decreased as the tests proceeded. The resistances of specimens 4 and 5 were nearly the same for every coating.

Although there were exceptions, it can be said in a very rough approximation, that at -1.02 volts and -1.07 volts there is a 
TABLE 5. FUSION BONDED EPOXY - APPARENT RESISTANCE IN OHMS

\begin{tabular}{|r|rrrrr|}
\hline & $\begin{array}{r}\text { SP. } 1 \\
\text { DAY }\end{array}$ & $\begin{array}{r}\text { SP. } 2 \\
-1.02 \mathrm{~V}\end{array}$ & $\begin{array}{r}\text { SP. } 3 \\
-1.07 \mathrm{~V}\end{array}$ & $\begin{array}{r}\text { SP. } 4 \\
-1.12 \mathrm{~V}\end{array}$ & $\begin{array}{r}\text { SP. } 5 \\
-1.22 \mathrm{~V}\end{array}$ \\
\hline & 3330 & 3240 & 1270 & 580 & 610 \\
2 & 5140 & 9380 & 1860 & 590 & 510 \\
5 & 9050 & 7830 & 3130 & 470 & 470 \\
6 & 9170 & 7890 & 2360 & 520 & 400 \\
7 & 10000 & 7200 & 3110 & 440 & 390 \\
8 & 10000 & 8260 & 3500 & 470 & 410 \\
9 & 7940 & 8570 & 3440 & 440 & 400 \\
12 & 12330 & 5790 & 5200 & 330 & 370 \\
13 & 9000 & 8180 & 5200 & 360 & 400 \\
14 & 12000 & 8800 & 5240 & 390 & 410 \\
15 & 12400 & 6000 & 5500 & 400 & 420 \\
16 & 13750 & 6670 & 7860 & 480 & 450 \\
19 & 16000 & 8460 & 9090 & 410 & 470 \\
20 & 14120 & 6960 & 10000 & 370 & 400 \\
21 & 16840 & 7220 & 9290 & 330 & 410 \\
22 & 19380 & 7180 & 10000 & 330 & 380 \\
23 & 22860 & 8000 & 11820 & 330 & 510 \\
26 & 23850 & 8670 & 14440 & 490 & 380 \\
27 & 22140 & 8670 & 14440 & 470 & 440 \\
28 & 17690 & 7670 & 13640 & 320 & 410 \\
29 & 26360 & 7390 & 13000 & 420 & 430 \\
30 & 24170 & 11200 & 16000 & 450 & 420 \\
& & & & & \\
\hline
\end{tabular}


TABLE 6. COAL TAR ENAMEL - APPARENT RESISTANCE IN OHMS

\begin{tabular}{|c|rrrrr|}
\hline & SP. 1 & SP. ${ }^{2}$ & SP. ${ }^{3}$ & SP. ${ }^{4}$ & SP. 5 \\
DAY & -1.02 & -1.07 & -1.12 & -1.17 & -1.22 \\
\hline & 889 & 815 & 769 & 675 & 729 \\
2 & 952 & 782 & 952 & 527 & 736 \\
5 & 8333 & 1455 & 1067 & 750 & 441 \\
6 & 7500 & 1053 & 1077 & 875 & 506 \\
7 & 10000 & 1600 & 873 & 577 & 393 \\
12 & 26667 & 7500 & 1200 & 514 & 573 \\
13 & 55000 & 7500 & 1250 & 480 & 571 \\
14 & 63333 & 30000 & 1250 & 446 & 560 \\
17 & 44000 & 55000 & 1325 & 504 & 543 \\
18 & 66667 & 40000 & 1310 & 455 & 574 \\
19 & 54286 & 40000 & 1364 & 536 & 542 \\
20 & 54286 & 26667 & 1538 & 538 & 516 \\
21 & 44000 & 33333 & 1477 & 452 & 643 \\
24 & 36364 & 63636 & 1644 & 816 & 583 \\
25 & 42000 & 48000 & 1781 & 434 & 583 \\
26 & 36000 & 55000 & 1739 & 474 & 604 \\
27 & 40000 & 40000 & 1594 & 471 & 511 \\
28 & 40000 & 25000 & 1818 & 514 & 530 \\
& & & & & \\
\hline
\end{tabular}


TABLE 7. TAPE - APPARENT RESISTANCE IN OHMS

\begin{tabular}{|c|c|c|c|c|c|}
\hline DAY & $\begin{array}{r}\text { SP. } 1 \\
-1.02 \mathrm{~V} \\
\end{array}$ & $\begin{array}{r}\text { SP. } \\
-1.07 V^{2} \\
\end{array}$ & $\begin{array}{r}\text { SP. }{ }^{3} \\
-1.12 \mathrm{~V} \\
\end{array}$ & $\begin{array}{r}\text { SP. }{ }^{4} \\
-1.17 \mathrm{~V} \\
\end{array}$ & $\begin{array}{r}\text { SP. } 5 \\
-1.22 \mathrm{~V} \\
\end{array}$ \\
\hline $\begin{array}{r}1 \\
4 \\
5 \\
6 \\
7 \\
8 \\
11 \\
12 \\
13 \\
14 \\
15 \\
18 \\
19 \\
20 \\
21 \\
22 \\
25 \\
26 \\
27 \\
28 \\
29\end{array}$ & $\begin{array}{r}882 \\
4200 \\
5000 \\
6800 \\
2230 \\
5000 \\
6000 \\
7000 \\
7600 \\
8200 \\
6780 \\
6000 \\
4750 \\
15000 \\
16000 \\
10330 \\
9500 \\
14000 \\
10330 \\
9330 \\
14000\end{array}$ & $\begin{array}{r}1440 \\
1820 \\
2420 \\
2920 \\
3380 \\
2820 \\
2500 \\
444 \\
4300 \\
3300 \\
3220 \\
3110 \\
8170 \\
5600 \\
5000 \\
18750 \\
9500 \\
12000 \\
9330 \\
11600 \\
11800\end{array}$ & $\begin{array}{l}1020 \\
1000 \\
1225 \\
1260 \\
1180 \\
136 ? \\
1380 \\
1031 \\
1240 \\
1510 \\
1300 \\
2060 \\
1780 \\
1800 \\
1710 \\
1780 \\
2140 \\
2120 \\
6210 \\
2090 \\
2440\end{array}$ & $\begin{array}{l}785 \\
634 \\
600 \\
600 \\
549 \\
450 \\
645 \\
153 \\
306 \\
606 \\
573 \\
559 \\
618 \\
568 \\
608 \\
620 \\
763 \\
592 \\
620 \\
520 \\
496\end{array}$ & $\begin{array}{r}772 \\
606 \\
566 \\
527 \\
579 \\
442 \\
495 \\
85 \\
560 \\
603 \\
603 \\
672 \\
689 \\
650 \\
627 \\
634 \\
720 \\
658 \\
572 \\
575 \\
611\end{array}$ \\
\hline
\end{tabular}


TABLE 8. ASPHALT - APPARENT RESISTANCE IN OHMS

\begin{tabular}{|c|c|c|c|c|c|}
\hline DAY & $\begin{array}{r}\text { SP. } 1 \\
-1.02 \mathrm{~V} \\
\end{array}$ & $\begin{array}{r}\text { SP. } 2 \\
-1.07 \mathrm{~V} \\
\end{array}$ & $\begin{array}{r}\text { SP. } 3 \\
-1.12 \mathrm{~V} \\
\end{array}$ & $\begin{array}{r}\text { SF. } 4 \\
-1.17 \mathrm{~V} \\
\end{array}$ & $\begin{array}{r}\text { SP. } 5 \\
-1.22 \mathrm{~V} \\
\end{array}$ \\
\hline 1 & 1234 & 1053 & 1192 & 1223 & 1124 \\
\hline 2 & 1351 & 1205 & 1193 & 824 & 1264 \\
\hline 3 & 1500 & 1200 & 1212 & 620 & 1319 \\
\hline 6 & 2083 & 1395 & 1241 & 711 & 525 \\
\hline 7 & 2381 & 1778 & 1283 & 730 & 513 \\
\hline 8 & 2353 & 1690 & 1236 & 671 & 464 \\
\hline 9 & 3846 & 1613 & 1245 & 662 & 484 \\
\hline 10 & 3000 & 1852 & 1304 & 706 & 551 \\
\hline 13 & 4286 & 1429 & 1154 & 641 & 626 \\
\hline 14 & 5000 & 1429 & 1265 & 630 & 592 \\
\hline 15 & 5000 & 1667 & 1261 & 811 & 589 \\
\hline 16 & 5455 & 1667 & 1261 & 604 & 606 \\
\hline 21 & 7500 & 2308 & 1238 & 640 & 699 \\
\hline 23 & 7500 & 2000 & 1300 & 733 & 771 \\
\hline 24 & 7500 & 2727 & 1389 & 722 & 804 \\
\hline 27 & 10000 & 3636 & 1371 & 719 & 919 \\
\hline 28 & 13333 & 3636 & 1294 & 719 & 957 \\
\hline 29 & 13333 & 2222 & 1294 & 763 & 889 \\
\hline 30 & 1333 & 2222 & 1294 & 750 & 706 \\
\hline
\end{tabular}

TABLE 9. DISBONDMENT RESULTS

\begin{tabular}{|c|c|c|c|c|c|c|c|c|}
\hline \multirow{2}{*}{$\begin{array}{l}\text { Potential } \\
\text { (IR Free) } \\
\text { Volts }\end{array}$} & \multicolumn{4}{|c|}{ Disbondment Area-sq.in. } & \multicolumn{4}{|c|}{ Percent Disbondment } \\
\hline & $\begin{array}{l}\text { Fusion } \\
\text { Bonded }\end{array}$ & $\begin{array}{l}\text { Coal } \\
\text { Tar } \\
\end{array}$ & $\begin{array}{l}\text { Plastic } \\
\text { Tape }\end{array}$ & Asphalt & $\begin{array}{l}\text { Fusion } \\
\text { Bonded }\end{array}$ & $\begin{array}{l}\text { Coal } \\
\text { Tar }\end{array}$ & $\begin{array}{l}\text { Plas } \\
\text { Tape }\end{array}$ & Asphalt \\
\hline-1.02 & 0 & 0 & 0 & 0 & 0 & 0 & 0 & 0 \\
\hline-1.07 & 0 & 0 & 0.020 & 0 & 0 & 0 & 5 & 0 \\
\hline-1.12 & 0.0437 & 0 & 0.058 & 0 & 10 & 0 & 13 & 0 \\
\hline-1.17 & 0.0625 & 0 & 0.095 & 0 & 14 & 0 & 21 & 0 \\
\hline-1.22 & 0.6830 & 0.0069 & 0.160 & 0 & 150 & 2 & 36 & 0 \\
\hline
\end{tabular}


substantial increase in resistance with respect to time as the tests proyressed; at -1.12 volts, the resistance remains unchanged or increases only sligntly; and at -1.17 volts and -1.22 volts remains at a low value or decreases.

There is a rough correlation between these findings and the amount of hydrogen evolution observed. At -1.02 volts and -1.07 volts, no gas evolution was observed; at -1.12 volts, some slight evolution of gas occurred; and at -1.17 volts and -1.22 volts, there was vigorous gas evolution.

\section{PHYSICAL EXAMINATION}

Although all of the specimens were examined for disbondment upon the completion of each test, it should be understood that the results yiven here are merely informational. Conclusions should not be drawn from this information concerning the disbondment resistance of any particular coating. Although all the coatings were subjected to the same levels of cathodic protection, it must be appreciated that these are very short terin tests conducted in water and that they would not necessarily be indicative of long term performance in an underground environment. In addition, the testing of only one sample of each coating at a given potential level is certainly not a sufficient sample on which to base general conclusions.

The disbondment results observed are listed in Table 9 (see page 18). These results show that the heavier coatings, i.e., asphalt and coal tar, showed better disbondment resistance than the fusion bonded epoxy and the plastic tape. The plastic tape showed disbondment even at a potential level $(-1.07)$ where there was no apparent gas evolved. It is interesting that the asphalt and coal tar showed little or no disbondment even at -1.22 volts in the presence of vigorous gas evolution. On the basis of these tests, it can be stated that there is no value of potential which can be considered to be a limit, that is, a value of potential Deyond which (more negative) disbondment always occurs and below which coatings do not disbond. For example, during these tests disbondment was found on the tape specimen at the relatively low negative OFF potential of -1.07 volts with corresponding on potentials less negative than -1.16 volts, while no disbondment was found on the asphalt specimen at the upper limit of OFF potential, -1.22 volts, and corresponding oN potentials more negative than -8.0 volts.

The above remarks are not intended to indicate that one coating is superior to another in disbondment resistance, but merely to show that under certain conditions, disbondment can occur at relatively low negative potentials and also that coatings can be found to be resistant at potential values which are often considered to be excessive. 


\section{CONCLUSIONS}

The results of the coating tests conducted in Houston tap water showed that:

1. Hydrogen evolution was initiated at an OFF potential of -1.12 volts to copper-copper sulfate and became vigorous at OFF potentials of -1.17 and -1.22 volts.

2. The most negative OFF potential obtainable was -1.22 volts. The OFF potential could not be made more negative than that value even with a substantial increase in applied current.

3. An increase in the current applied to a specimen at an OFF potential of -1.22 resulted in increased hydrogen evolution and an increase in the negstive ON potential, but the OFF potential remain unchanged.

4. The OFF potential could not bo directly related to the on potential and, therefore, the oN potential is not considered to be a valid indicator of hydrogen evolution.

5. Hydrogen evolution by itself did not produce coating disbondment in all cases in these short term tests. On the other hand, one specimen showed disbondment even though there was no visible yas evolution. 
1. RP-01-69 (1972 Revision), "Control of External Corrosion on Underground or Submerged Metallic Piping Systems," paragraph 1.2. National Association of Corrosion Engineers, Houston, Texas.

2. Boysen, S. "Coatings Fundamentals" Proceedings of the Twentieth Annual Appalachian Underground Corrosion Short Course, West Virginia University, 1975, Pages 332-337.

3. CP1021:1973 "Code of Practice for Cathodic Protection," Paragraph 3.8.1. British Standards Institution, London.

4. Backstrom, T.E. and Causey, F.E., "Effects of Cathodic Protection on Protective Coatings," Report No. ChE-71 United States Department of Interior, Bureau of Reclamation, February 1969, Page 1.

5. Peabody, A.W., "Control of Pipeline Corrosion", National Association of Corrosion Engineers, Houston, Texas, Page 22.

6. Op. Cit. Reference 2, Paragraph 8.3.3.3.

7. Hunter, J.N., "Evaluation of Pipeline Coatings," Material Performance, vol. 3, No. 2 (February 1964), Page 50-59.

8. "Screening Test for Pipeline Tape Coatings," Staff Feature, Materials protection, Vol. 1, No. 1, (January 1962) Pages 10-14.

9. "Laboratory Evaluation of Coatings," Staff Feature, Materials Protection, Vol. 1, No. 6 (June 1962) Pages 10-15.

10. Goose, J.F. "Pipe Coating Burial Tests and Their Correlation with Laboratory Tests,: Proceedings of the Seventeenth Annual Appalachian Underground Corrosion Short Course. West Virginia University, 1974, Pages 109

11. OP. Cit. Reference 3, Page 4.

12. Standard Methods of Test for Cathodic Disbonding of Pipeline Coatings," American Society for 'Testing and Materials, Designation: G8-72.

13. "Standard Method of Test for Disbonding Characteristics of Pipeline Coating by Direct Soil Burial," American Society for Materials protection, Designation: G19-72. 


\section{FUSION BONDED EPOXY}

The fusion bonded epoxy coating used in this study is known commercially as "Scotchkote" Brand 212 Fusion Bonded Epoxy Coating as manufactured by the $3 \mathrm{M}$ Company. It is described by the manufacturer as a one-part, heat curable, thermosetting powdered epoxy coating. It is applied to pipe preheated to approximately $450^{\circ} \mathrm{F}$ after being cleaned by removing oil, grease and loosely adhering deposits and prepared by abrasive blast to NACE near white. The 212 powder is deposited electrostatica'ly to a minimum thickness of $10 \mathrm{mils}$ $(.254 \mathrm{~mm})$. A-1.

The manufacturer's literature lists the properties given in Table

TABLE A-1. PROPERTIES OF FUSION BONDED EPOXY

\begin{tabular}{ll} 
PROPERTY & VALUE \\
\cline { 2 - 2 } Color & Brown \\
Specific Gravity & 1.35 \\
$\begin{array}{l}\text { Coverage } 10 \mathrm{mil} \\
(2.54 \mathrm{~mm}) \text { coating }\end{array}$ & $\begin{array}{l}14.2 \mathrm{ft}^{2} / 1 \mathrm{~b} \\
\left(2.59 \mathrm{~m}^{2} / \mathrm{kg}\right)\end{array}$ \\
$\begin{array}{l}\text { Shelf life at } 80^{\circ} \mathrm{F} \\
\left(27^{\circ} \mathrm{C}\right)\end{array}$ & $12 \mathrm{months}$ \\
$\begin{array}{l}\text { Gel time at } 400^{\circ} \mathrm{F} \\
\left(204^{\circ} \mathrm{C}\right)\end{array}$ & $9 \mathrm{secs}$. \\
$\begin{array}{l}\text { Explosibility minimum } \\
\text { explosive concentration }\end{array}$ & $30.6 \mathrm{gms} / \mathrm{m}^{3}$
\end{tabular}

Test data excerpted from the manufacturer's literature is given in Table $\mathrm{A}-2$.

TABLE A-2. TEST DATA

\begin{tabular}{|c|c|c|}
\hline Property & Test Description & Results \\
\hline Impact & $\begin{array}{l}\text { ASTM G-14 } \\
1 / 8 \text { in. } x 3 \text { in. } x 3 \text { in. }(.32 \mathrm{~cm} \times 7.6 \\
\text { cm } x 7.6 \mathrm{~cm}) \text { steel panel } 5 / 8 \text { in. } \\
(1.6 \mathrm{~cm}) \text { Radius Tup }\end{array}$ & 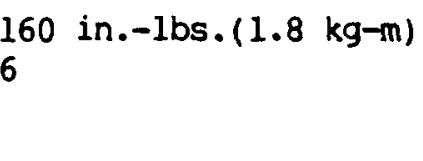 \\
\hline
\end{tabular}




\begin{tabular}{|c|c|c|}
\hline Property & Test Description & Results \\
\hline $\begin{array}{l}\text { Abrasion } \\
\text { Resistance }\end{array}$ & $\begin{array}{l}\text { ASTM D - 1044 } \\
\text { CS } 17,1,000 \text { gm weight } \\
5,000 \text { cycles }\end{array}$ & $0.0664 \mathrm{gm} \mathrm{loss}$ \\
\hline $\begin{array}{l}\text { Abrasion } \\
\text { Steel (Shear) }\end{array}$ & $\begin{array}{l}\text { ASTM D-1002 } \\
10 \mathrm{mil}(0.254 \mathrm{mn}) \mathrm{glue} \text { line }\end{array}$ & $\begin{array}{l}5,300 \mathrm{psi} \\
376 \mathrm{~kg} / \mathrm{sq} . \mathrm{cm} .\end{array}$ \\
\hline Penetration* & $\begin{array}{l}\text { ASTM G-17 } \\
-40^{\circ} \mathrm{F} \text { to } 240^{\circ} \mathrm{F} \\
\left(-40^{\circ} \mathrm{C} \text { to } 116^{\circ} \mathrm{C}\right)\end{array}$ & 0 \\
\hline Iensile Strength & ASTM D-2370 & $\begin{array}{l}10,000 \mathrm{psi} \\
710 \mathrm{~kg} / \mathrm{sq} . \mathrm{cm} .\end{array}$ \\
\hline Elongation & ASTM D-2370 & 7.18 \\
\hline $\begin{array}{l}\text { Compressive } \\
\text { Strength }\end{array}$ & ASTM D-695 & $\begin{array}{l}13,700 \mathrm{psi} \\
973 \mathrm{~kg} / \mathrm{sq} . \mathrm{cm} .\end{array}$ \\
\hline Thermal Shock & $\begin{array}{l}3100 \mathrm{~F} \text { to }-1000^{\circ} \mathrm{F}\left(154^{\circ} \mathrm{C}\right. \\
\left.\text { to }-73^{\circ} \mathrm{C}\right) 4 \text { in. } x 4 \text { in. }(10.2 \mathrm{~cm} \\
x 10.2 \mathrm{~cm}) \text { coated panel }\end{array}$ & 10 cycles no effect \\
\hline Volume Resistivity & ASTM D-257 & $1.27 \times 10^{17} \mathrm{ohm} \mathrm{cm}$ \\
\hline Salt Fog & $\begin{array}{l}\text { ASTM B }-117 \\
1,000 \text { hours }\end{array}$ & $\begin{array}{l}\text { No blistering, no } \\
\text { discoloration, no } \\
\text { loss of adhesion }\end{array}$ \\
\hline \multirow[t]{4}{*}{ Salt Crock* } & 90 day, 5 volt, 58 NACL & $\begin{array}{l}\text { Disbondment diameter } \\
50 \mathrm{~mm} \text { average }\end{array}$ \\
\hline & $\begin{array}{l}90 \text { day, } 1.5 \text { volt }, 38, \text { ASTM G- } 8 \\
\text { salt solution }\end{array}$ & $\begin{array}{l}\text { Disbondment diameter } \\
51 \mathrm{~mm} \text { average }\end{array}$ \\
\hline & $\begin{array}{l}90 \text { day, } 6 \text { volt }, 38, \text { ASTM } ज-8 \\
\text { salt solution }\end{array}$ & $\begin{array}{l}\text { Disbondment diameter } \\
46 \mathrm{~mm} \text { average }\end{array}$ \\
\hline & $\begin{array}{l}180 \text { day, } 1.5 \text { volt }, 38, A S T M-8 \\
\text { salt solution } \\
\text { sand crock } 230^{\circ} \mathrm{F}\left(110^{\circ} \mathrm{C}\right) \\
\text { panel temperature, } 22 \mathrm{mil} \\
(0.560 \mathrm{~mm}) \text { coating thickness }\end{array}$ & $\begin{array}{l}\text { Disbonument diameter } \\
39 \mathrm{~mm} \text { average }\end{array}$ \\
\hline $\begin{array}{l}\text { Hot Water } \\
\text { Resistance* }\end{array}$ & $\begin{array}{l}190^{\circ} \mathrm{F}\left(88^{\circ} \mathrm{C}\right) \text { immersion } \\
2,200 \text { hours }\end{array}$ & $\begin{array}{l}\text { Surface roughness and } \\
\text { small surface blisters, } \\
\text { coat softer, good } \\
\text { adhesion }\end{array}$ \\
\hline
\end{tabular}


Property

Hot Water

Resistance

Bendability ${ }^{\star}$

Pipe coupon mandrel bend at $73^{\circ} \mathrm{F}\left(23^{\circ} \mathrm{C}\right)$

Pipe coupon mandrel bend at $0^{\circ} \mathrm{F}\left(-18^{\circ} \mathrm{C}\right)$

\section{Results}

slight color change, very slight softening, excellent adhesion

Very slight color change, excellent adhesion

15 pipe diameters average

15 pipe diameters average

* Tests conducted on two $3 / 8$ inch $(60 \mathrm{~mm}$ ) OD production coated pipe. 
The coal tar enamel coating used in this study is Bitumastic 70-B Standard Enamel as manufactured by Koppers Company. It is described by the manufacturer as a fully plasticized enamel covering a wide temperature range. It is applied to a pipe whose surface is prepared by blasting to meet NACE Standard TM-01-70, Visual Standards, between NACE NO. 3 and NACE No. 2. After a primary coat of 70-B primer, the enamel is hot-applied to produce a coating thickness of $3 / 32$ " minimum.

The manufacturer's literature lists the characteristics given in Table A-3.

TABLE A-3. CHARACTERISTICS OF BITUMASTIC ENAMELS

BITUMASTIC

70-B STO

Characteristic

Enamel

Softening point $\left(O_{F}\right)$

ASTM C36 ( $R \& B)$

220-235

ASH (8)

By weight by ignition

25-35

Specific Gravity at $77^{\circ} \mathrm{F}$

ASTM D71

$1.40-1.60$

Penetration (ASTM D5)

at $77^{\circ} \mathrm{F}$

at $115^{\circ} \mathrm{F}$

4-9

12-25

SAG (1/16-in.max.)

AWWA C203-62

24 hours

at $160^{\circ} \mathrm{F}$

Crack (none)

6 hours

AWWA C203-62

at $-10^{\circ} \mathrm{F}$

Normal Application

Temperature $\left(\mathrm{O}_{\mathrm{F}}\right)$

$450-490$

Temperature Exposure

Range ( $O_{F}$ )

-10 to 160 


\section{PLASTIC TAPE}

The plastic tape coating used in this study is a cold-applied, self-adhesive pipe wrap known as Servi-Wrap P-400 as manufactured by w. R. Grace \& company. It is described by the manufacturer as a "tough, pliable, corrosion resistant pipe wrap" that "provides a dual seal of a cross laminate, high density polyethylene film combined with a thick, factory controlled layer of adhesive-consistency, bituminous rubber compound." It was applied to a clean and dry pipe surface in accordance with the manufacturer's recomendations.

The manufacturers literature lists the physical properties given in Table A-4.

TABLE A-4. TYPICAL PHYSICAL PROPERTIES OF PLASTIC TAPE

\begin{tabular}{|c|c|c|}
\hline Property & Value & Test Method \\
\hline Color & Dark Grey-Black & \\
\hline Thickness & $\begin{array}{l}\text { Compound } 40 \mathrm{Mils} \\
\text { Film } \\
\begin{array}{ll}\text { Total } & 4 \mathrm{Mils} \\
4 \mathrm{Mils}\end{array}\end{array}$ & \\
\hline Tensile Strength & 5125 psi & ASTM D-882-56T \\
\hline Elongation at Break & 2058 & ASTM D-882-56T \\
\hline $\begin{array}{c}\text { Impact Resistance (1) } \\
\text { Single Layer } \\
\text { Double Layer }\end{array}$ & $\begin{array}{l}13 \mathrm{~kg} \mathrm{Om} \\
39\end{array}$ & ASTM G-14 \\
\hline Puncture Resistance (2) & $57 \mathrm{lb}$ & ASTM E-154 \\
\hline $\begin{aligned} \text { Adhesion to Steel - Initial } & \\
& 30 \mathrm{Min}\end{aligned}$ & $\begin{array}{l}6 \mathrm{lb} \\
8 \mathrm{lb} / \mathrm{in} .\end{array}$ & DIN 30670 Modified \\
\hline $\begin{aligned} \text { Adhesion to Self } & - \text { Initial } \\
& 30 \mathrm{Min}\end{aligned}$ & $\begin{array}{l}3 \mathrm{lb} / \mathrm{in} . \\
4 \mathrm{lb} / \mathrm{in} .\end{array}$ & \\
\hline $\begin{array}{l}\text { Permeance-Perms. (3) } \\
\text { Pliability (4) }\end{array}$ & $\begin{array}{l}0.1 \text { Max. } \\
\text { Pass }\end{array}$ & $\begin{array}{l}\text { ASTM E-96 Method B } \\
\text { ASTM C-711 }\end{array}$ \\
\hline $\begin{array}{l}\text { Exposure to Fungi } \\
\text { In soil - } 16 \text { weeks }\end{array}$ & Unaffected & \\
\hline $\begin{array}{l}\text { Alkali \& Acid Resistance } \\
\text { Dielectric Breakdown }\end{array}$ & $\begin{array}{l}\text { Excellent } \\
9700 \text { volts }\end{array}$ & ASTM D-149 \\
\hline
\end{tabular}


Property

Resistance to Cathodic Disbondment

Conformability

Operating Temperature Range Application Temperature Range
Value

Excellent

Excellent

$-25^{\circ} \mathrm{F}$. to $150^{\circ} \mathrm{F}$. $40^{\circ} \mathrm{F}$. to $120^{\circ} \mathrm{F}$.

Notes: (1) Film Break

(2) Stretched by Blunt object

(3) Grains/Sq Ft / Hr / In Hg

(4) $180^{\circ}$ Bend Over $1 / 4$ inch Mandrel a $-35^{\circ} \mathrm{F}$. 


\section{ASPHALT COATING}

The asphalt coating used in this study, identified by the trade mark Somastic, is manufactured and applied by H. C. Price Company. The manufacturer describes this coating as a dense mixture of asphalt-mastic. Typical general proportions of material in the mastic $\mathrm{mix}$ are as follows:

Asphalt

Aggregate: Sand and Lime Filler
108 to 128 by weight

888 to 908 by weight

0.108 to 0.158 by weight

Fiber

"The materials are blended and mixed in a specially built asphalt-mastic heating plant designed to maintain absolute control on proportions and temperatures of the mix. Pug mills are used to deliver a continuous flow of mastic from the machine, sufficient mixing time being alloted to secure a final homogeneous coating weighing approximately 135 pounds per cubic foot."

The pipe surface is prepared by preheating to drive off moisture, then cleaned and steel shot blasted. A hot primer is applied and the asphalt-mastic mixture is extruded over the circumference of the primed pipe in a continuous process to form a uniformly thick, seamless coating. The coating thickness on the specimens used in this study was $3 / 8$ " nominal and 5/16" minimum.

The specifications derived from the manufacturer's literature are:

1. PRIMER - .35 Gallon per 100 square foot Minimum Somastic Primer produced from manufactured asphalt, natural asphalt and appropriate petroleum thinner.

2. ASPHALT ( $10 \%$ to 128 by weight)

\begin{tabular}{|c|c|c|c|}
\hline Operating Temperature, ${ }^{\circ}$ & $120-$ & $150--$ & $190-$ \\
\hline $\begin{array}{l}\text { Softening point } \\
\text { (Ring and Ball), of }\end{array}$ & $150-175$ & $175-200$ & $210-220$ \\
\hline $\begin{array}{l}\text { Penetration at } 77^{\circ} \\
100 \mathrm{~g}, 5 \mathrm{sec}\end{array}$ & $21-26$ & $15-17$ & $7-11$ \\
\hline $\begin{array}{l}\text { Flash Point } \\
\text { (Cleveland open Cup), OF }\end{array}$ & 450 & 450 & 450 \\
\hline $\begin{array}{l}\text { Loss on Heating at } 325^{\circ} \mathrm{F} \text {, } \\
5 \text { hour }, 8\end{array}$ & 0.5 & 0.5 & 0.5 \\
\hline Ductility at $77^{\circ} \mathrm{F}, \mathrm{cm}$ & 3.5 & 3.5 & 1.0 \\
\hline Percent soluble in $\mathrm{CCL}_{4}$ & 99.0 & 99.0 & 99.0 \\
\hline
\end{tabular}


3. AGGREGATE ( 888 to 908 by Weight)

Clean non-micaceous and graded to maximum density.

(a) Sand

1008 Passing 6 Mesh U.S. Standard Screen

(b) Mineral Filler

Crushed Stone or Equivalent minimum $75 \%$ by weight

passes 200 Mesh U. S. Standard Screen; 100\% passes 50

Mesh U. S. Standard Screen.

4. FIBER (0.108 to .158 by Weight of Total Mastic Materials) It $a$ individual filaments shall be predominately one-fourth to one inch in length and have a nominal diameter of 0.0001 to 0.001 inch as determined by Owens-Corning Fiberglass Test Method No. TF-515K for nominal filament diameter. 
APPENDIX B

HOUSTON TAP WATER ANALYSIS RESULTS

The chemical and semiquantitative spectrographic analyses are given in Tables B-1 and B-2, respectively.

TABLE B-1. CHEMICAL ANALYSIS

Chloride, $\mathrm{mg} / \mathrm{l}$

Sulfate, $\mathrm{mg} / \mathrm{l}$

Nitrate Nitrogen, $\mathrm{mg} / \mathrm{l}$

Dissolved Oxygen, $\mathrm{mg} / 1$

Total Solids, $\mathrm{mg} / 1$

Total Fixed Solids, mg/l

pH

Specific Conductance, mho/cm

Alkalinity, $\mathrm{mg} / \mathrm{l}$
40.

2.0

0.14

7.0

305.

256.

7.0

430.0

172.0

TABLE B-2. SEMIQUANTITATIVE SPECTROGRAPHIC ANALYSIS

Elements

Calcium

Magnesium

Sodium

Iron

Silicon

Aluminum

Boron

Copper
Approximate No. of $\mathrm{mg} / \mathrm{l}$

167.

6.

4.

0.5

0.7

0.1

0.2

0.1 
INITAL DISTRIBUTION

HQ AFSC/DEEE

HQ ATC/DEMM

HO SAC/DEEM

HQ PACAF/DEEEE

HQ MAC/DE

HQ TAC/DE

HO AAC/DEEE

HQ AFLC/DEMG

HQ USAFE/DEMO

AFIT/DET

HQ AUL/LSE 71-249

AFIT/Tech Library

USAFA/DFCEM

DTIC/DDA

HQ AFRES/DEMM

FAA/RD430

ANGSC/DEM

CERF

CERL

USANES

HQ AFESC/TST

HQ AFESC/DEMM

HQ AFESC/RDCF

AFATL/DLODR

AFATL/DLODL

(The reverse of this page is blank.) 


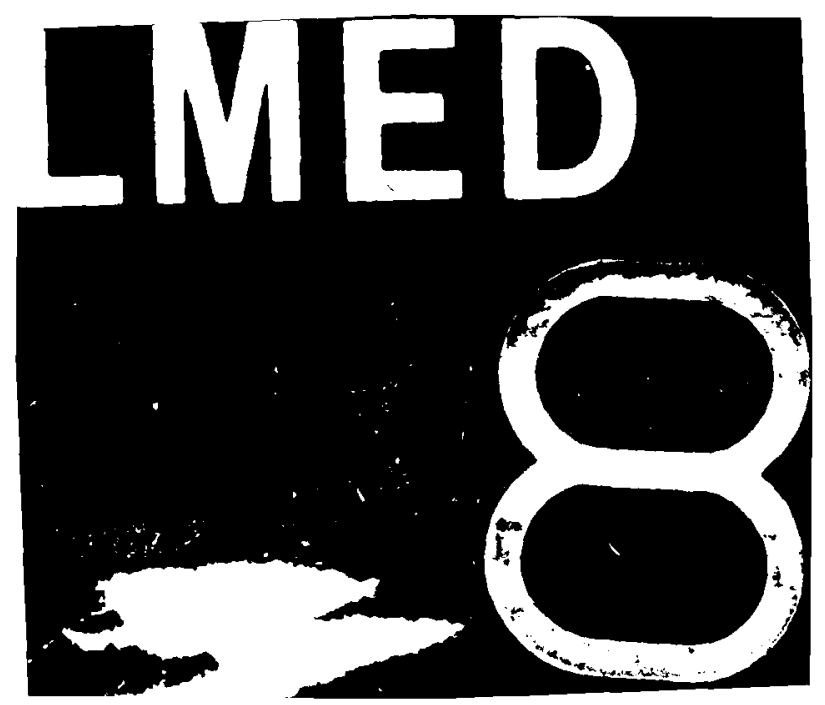

